„Tehetség, szorgalom, hivatás”

\author{
Tanulmánykötet
}

Kézirat lezárva: 2021. június 25. 
Kiadja:

a Magyar Rendészettudományi Társaság

Vám- és Pénzügyőri Tagozata

Szerkesztette:

Csaba Zágon és

Zsámbokiné Ficskovszky Ágnes

Felelős kiadó:

Szabó Andrea

ISBN: 978-615-81879-0-9

A mú szerzői jogilag védett. Minden jog, így különösen a sokszorosítás, terjesztés és fordítás joga fenntartva. A mű a kiadó írásbeli hozzájárulása nélkül részeiben sem reprodukálható, elektronikus rendszerek felhasználásával nem dolgozható fel, azokban nem tárolható, azokkal nem sokszorosítható és nem terjeszthetô. 
Szerzők

Lektorok

Lectori Salutem!

Tanulmányok

Christián László - Lippai Zsolt: Kakukktojás vagy új rendészeti alappillér?

Gonda Éva: Az Europol hospitáció hasznosítása a pénzügyi nyomozók képzése terén

Kakócz Krisztián - Vedó Attila: A toloncolás szabály- és szervezetrendszere a második világháború előtt

Kovács Gábor: A vezetői kompetenciák fejlesztésének lehetőségei a Rendészettudományi Kar hallgatóinak körében

Magasvári Adrienn: Egy új jogviszony „születése” - az adó- és vámhatósági szolgálati jogviszony vizsgálata ..

Molnár Katalin: Mi harminc? Tudománymetria helyett - Szerzőtársas játék................................ 87

Nyeste Péter: A modern bűnügyi hírszerzés modelljeinek fejlődése ............................................ 103

Pajor Andrea: Adóigazgatási tisztviselők képzése .

Sallai János - Borszéki Judit: Egy megvalósítható utópia? Közös munkanyelv keresése a nemzetközi rendőri együttmúködés kezdetén.

Suba László: Nyelvhelyesség a közszférában: Létkérdés vagy úri huncutság?

Szabó Andrea - Hájer Tamara: A vámfelsőoktatás uniós elismerési eljárásának elemei

Szlifka Gábor: Okos adózás, okos adóigazgatás - Minden ami okos, de mit is jelent pontosan?

Kutatási eredmények

Balla József - Kiss Lajos: A rendvédelmi szervező szakirányú továbbképzési szak indításának legfontosabb tapasztalatai.

Borzán Anita - Szekeres Bernadett: A digitalizáció hatása a gazdasági szakismeretek és a számvitel oktatására.

Duchon Jenő: Tanulási stílus és játékos típus összevetése felnőtteknél, az oktatási folyamat játékosítása céljából

Erdős Ákos - Somogyi Ágnes: Koffeinhasználat és koffeinhasználati zavar vizsgálata rendészeti hallgatók körében

Halasi Nóra: Feltáró kutatás a hivatástudat és motiváció jelentőségének vizsgálatára, a Hajdú-

Bihar Megyei Adó- és Vámigazgatóság személyi állományának összefüggésében 251 
DOI: $10.37372 / \mathrm{mrttvpt} .2021 .1 .10$

\title{
Suba László: Nyelvhelyesség a közszférában: Létkérdés vagy úri huncutság?
}

\author{
„A magyart is tanulni kell, még a sұületett magyarnak is. \\ Ha nem csiszolja, újítja folytonosan, berozsdásodik."
}

/Kodály Zoltán/

\begin{abstract}
Absztrakt
A szerző azt vizsgálja tanulmányában, hogy milyen szerepe van a nyelv helyes használatának - kiemelten a helyesírásnak és a helyesejtésnek - az állami (közigazgatási, rendészeti) szervezetek múködésében. A kérdést három oldalról közelíti meg: a szervezeti kultúra szempontjából, a nyelvmúvelés felől, illetve a gyakorlati hasznosság oldaláról. A téma kifejtéséhez elméleti alapként szolgál a magyar nyelv sztenderdizációjának a vizsgálata, ezzel összefüggésben pedig a nyelvművelés történetének rövid áttekintése és szerepének bemutatása. A leíró és az előíró nyelvészet körüli viták felvillantása után a szerző utóbbi mellett foglal állást, s ezen az elvi alapon érvel a nyelvhasználat, mint a szervezeti kultúra egyik látható elemének kiemelkedő fontossága mellett.
\end{abstract}

Kulcsszavak: kö̈igazgatás, Nemzeti Adó- és Vámbivatal, nyelv, rendészet, szervezeti kultúra;

\begin{abstract}
In his study, the author examines the role of the correct use of language - especially correct writing and correct pronunciation - in the functioning of state (administrative, law enforcement) organizations. It examines three sides: organizational culture, language education, and the practical usefulness perspectives. The theoretical basis of this topic is exploring the standardization opportunities of the Hungarian language and a brief overview of the history of language education. After sparking controversy over descriptive and prescriptive linguistics, the author favours the latter, arguing on this moral basis for the paramount importance of language use as a visible element of organizational culture.
\end{abstract}

Keywords: Administration, organizational culture, public administration.

\section{A helyesírásról és a helyesejtésről}

Szerény, egyáltalán nem tudományos értékủ, de annál határozottabb tapasztalataim szerint az emberek döntő többsége - a nyolc osztályt végzettektől a tudományos fokozattal bírókig - hadilábon áll a helyesírással. Ki-ki a maga szintjén persze: a legkevésbé múvelt embertársaink számára olykor még egyszerű magyar szavak leírása is gondot okoz, a magas szintű tudományos problémákkal foglalkozók pedig sokszor olyan hibákat ejtenek, amelyek nem tekinthetők ugyan súlyosnak, mégis csökkentik az általuk papírra vetett gondolatok

\footnotetext{
* Suba László dr., pénzügyőr alezredes, tanársegéd, Nemzeti Közszolgálati Egyetem Rendészettudományi Kar,
} Vám- és Pénzügyőri Tanszék, https://orcid.org/0000-0001-6251-4654, suba.laszlo@,uni-nke.hu 
értékét. „A helyesírás a nyilvános, hivatalos írásbeliség szabályokba foglalt, elvárt írásmódja. Ezt tanítják az iskolákban, ezt kérik számon a hivatalos, nyilvános fórumokon. Azonban létezik, létezhet ettől eltérő írásgyakorlat is. Az iskolások sokszor produkálnak nem helyes formákat. Ezt az iskola rossz jeggyel torolja meg. Mivel nem mindenki tanulja meg alaposan a helyesírást, sokaknak egész életére rossz, szégyenletes emlék marad az írás, vagy egyáltalán nem írnak, vagy csak maguknak, és nem mutatják meg másoknak. Ha megmutatják, mindig szabadkoznak: ezt csak magamnak írtam, nem felel meg az elvárt írásbeli követelményeknek." 368

\section{Leiró vagy elöiró nyelvészet?}

Az európai nyelvek többsége - köztük a magyar nyelv is - sztenderdizált, ráadásul a magyar nyelvi kultúrát erôs normaközpontúság jellemzi. Egy nyelv sztenderd változatának kialakítása a sztenderdizáció, amely egy társadalmi, gazdasági vagy politikai hatalommal rendelkező csoporthoz köthető. Ez a folyamat Magyarországon a 19. század első felében ment végbe, a sztenderd változat társadalmi megitélésének változása azonban csak egy évszázaddal később következett be: a 20. század első felében fölértékelődött a sztenderd változat, ezzel együtt a nem-sztenderd (területi) változatok leértékelődtek. ${ }^{369}$ Nagy Lásそló úgy vélekedik, hogy a sztenderd változat jellemzésénél csak az írott sztenderdről lehet tulajdonságokat megfogalmazni, mert a beszélt sztenderd változat nem határolható körül úgy, mint a kodifikált normának megfelelő írott sztenderd. ${ }^{370}$ Nézetem szerint ugyanakkor a beszélt nyelvben is föllelhető sztenderd változat, igaz, hogy ez jóval több variációban (vagy pontosabban: több szinten) létezik, mint az írott magyar nyelv sztenderd változata. Az írott nyelvi sztenderd csupán alakváltozatokat enged meg (fel/föl, e-mail/ímél, tbc/tébécé stb.), ${ }^{371}$ míg a beszélt nyelv sztenderdizált változatának tekinthető elsősorban a közszolgálati rádió bemondóinak beszéde, azonban e szint alatt is léteznek a beszélt nyelvnek olyan változatai, amelyeket még sztenderdnek tekinthetünk (pl. a közszolgálati rádiós/televíziós műsorvezetőké vagy a tanároké). Adódhat az ellenvetés, hogy a rádióbemondó beszéde művi, mesterkélt, így soha senki nem beszél. Pedig mindössze arról van szó, hogy a rádióbemondó előadói eszközökkel éri el azt a hitelességet, amely a köznapi beszéd sajátja. „Köznapi beszédünk során arra külön nem kell figyelnünk, hogy mikor emelkedjen a hangunk, egy-egy szóra mikor kerüljön nyomaték." "372 A rádió-előadók beszédére viszont jellemző, hogy „az automatizmus beszédünk elemeit nem vezérli, s csupán képességeinkre, ügyességünkre vagyunk utalva, hogy mondandónkat hitelesnek tűnően, pontosan, jól érthetően adjuk elő". 373

A nyelv sztenderdizációjával kapcsolatban merül föl a lingvicizmus fogalma. Ez nem más, mint nyelvi alapú diszkrimináció: a lingvicizmus ideológiája szerint egyes emberek jól, mások pedig nem jól beszélik/használják a nyelvet. Lingvicizmus az is, amikor valakit a nemsztenderd formák miatt ér hátrányos megkülönböztetés, például az iskolai oktatásban. ${ }^{374}$

\footnotetext{
${ }^{368}$ BALÁZs Géza: Hatalom és helyesírás. In: BOZsIK Gabriella (szerk.): Két évtized a helyesírásért. EKF Líceum Kiadó, Eger, 2008. pp. 15-27.

${ }^{369}$ NAGY László: Metanyelvi ismeretek, nyelvi attitűdök, értékítéletek vizsgálata tanítójelöltek körében. Doktori értekezés. Szeged, 2018. p. 15. https://doi.org/10.14232/phd.9886

370 NAGY i. m. (2018) p. 16.

371 Vö. A magyar helyesírás szabályai. 12. kiad. Akadémiai Kiadó, Bp., 2015.

372 HorvátH Lajos: Beszéd a rádióban. Tanácsok kezdőknek és haladóknak. Magyar Rádió Rt., Bp., 2002. p. 31.

373 HORVÁTH i. m. (2002) p. 32.

374 NAGY i. m. (2018) p. 17.
} 
Nagy ismerteti a lingvicizmus visszaszorításának lehetséges módszereit, köztük Sándor nézetét, aki a nyelvi bizonytalanság csökkentésében és a nyelvi türelem eszményének nyelvészek közreműködésével való terjesztésében látja a megoldást - közelebbről például az iskolai oktatás során a megbélyegző javítások kerülésében. 375 , 376

A nyelv sztenderdizációja és az ezzel összefüggésben létező lingvicizmus problémaköre fölveti a kérdést: szükség van-e leiró nyelvészet helyett/mellett elöíró nyelvészetre? Sándor Klára ezzel kapcsolatban így érvel: „Elég arra gondolni, mi lenne a véleményünk arról a fizikusról, aki nem leírni akarná, hogy az inga hogyan mozog, vagy hogy egy leesô tárgy hogyan gyorsul, hanem előírni, hogy ezt hogyan tegye; mit gondolnánk arról az etológusról, aki nem megfigyelni és leírni akarná az állatok viselkedését, hanem rávenni őket, hogy úgy viselkedjenek, ahogyan szerinte egy tigrisnek, egy sasnak vagy egy kutyának viselkednie illik; vagy mi a véleményünk azokról a történészekről, akik nem a meglévő adatokat, hanem politikai érdekeket vagy saját ízlésüket követve írják a történelmet." ${ }^{377}$ Ezzel szemben Balázs Géza szerint „a nyelvművelődés (tanítás és önálló tanulás) célja $[\ldots]$ az egyén nyelvhasználatában bizonyos automatizmusok, valamint az önreflexivitás, a saját nyelvhasználatra való figyelés képességének kialakítása. Ehhez jó szolgálatot tehet a kétségtelenül egyfajta »elit«, magasabb rendű műveltséget sugalló - hibáztató nyelvmúvelés is, amely hozzájárul a »hibaérzék« növeléséhez”.378

\section{A belyesirás és a belyesejtés szerepe a mindennapokban}

Magyarországon történelmileg úgy alakult a helyzet, hogy az elöíró nyelvészet még mindig erôteljesen jelen van a mindennapokban. Az iskolában a nyelvtanórákon nem csupán a magyar leíró nyelvtan egyes részeit tanuljuk (a hangtant, a szófajtant, a mondattant stb.), tehát nem csupán ismereteket szerzünk a magyar nyelvről. Emellett még nyelvművelő munka is folyik, hiszen a helyesírási és nyelvhelyességi ismeretek megtanítása, az e téren ejtett tanulói hibák érdemjeggyel való értékelése, továbbá a hibák kijavítása ekként értékelhető vagyis a tanár elöírja a diáknak, hogy hogyan használja a magyar nyelvet. „A hazai kerettantervekben és a 2020-ban módosítottnak címkézett, valójában azonban teljesen új Nemzeti alaptantervben [...] nem csekély szerep jut a helyesírásnak: mint témakör és mint elérendő cél, elsajátítandó ismeret, készség számos helyen és formában egyaránt megjelenik a szabályozó dokumentumokban." ${ }^{379}$ Az iskola falain kívül is folyik/folyt nyelvmúvelés, például az igényes médiában. Hogy csak néhány példát említsek a múltból és a jelenből: a Magyar Rádióban Édes anyanyelvünk címmel Lőrincze Lajos músora, Beszélni nehéz! címmel Péchy Blanka és Deme László heti tízperce, vagy a Balázs Géza nevével fémjelzett Tetten ért szavak; a közszolgálati televíziókban a $H e j$, hej, helyesirás szintén Balázs Gézával, vagy korábban Grétsy László és Vágó István közös műsora Álljunk meg egy szóra! címmel. Ha olyan nyelvmúvelésre keresünk példát, amely nem „házhoz jön”, hanem mi magunk kereshetjük föl, akkor a többi között a Magyar Nyelvi Szolgáltató Irodát, a Manyszit említhetjük, amely folyamatosan és ingyenesen ad segítséget helyesírási kérdésekben bárkinek, aki az ott

\footnotetext{
375 uo.

376 Vö. SÁNDOR Klára: „A nyílt társadalmi diszkrimináció utolsó bástyája” az emberek nyelvhasználata. Replika, 2001/11. szám. pp. 241-259. http://real.mtak.hu/22329/

377 SÁNDOR i. m. (2001).

378 BALÁzs Géza: A fenntartható magyar nyelv. Nyelvépítészet - nyelvösszeomlás - nyelvstratégia. Inter-IKU, Bp., 2018. p. 33.

${ }^{379}$ JÁNK István: A helyesírás-tanítás helye és szerepe a nyelvtanórán és az iskolában. ACTA Universitatis de Carolo Eszterházy nominatae, Sectio Linguistica Hungarica, 2020/46. szám. pp. 45-56. https://doi.org/10.46437/actauniveszterhazylinguistica.2020.45
} 
dolgozó nyelvészekhez fordul. A mai napig is múködő, bár kifejezetten a nyelvhasználat szabadságát hirdetô műsor a Klubrádióban a Nádasdy Ádám és Kálmán László által vezetett Szószátyár.

Ha meg akarjuk érteni, hogy miért vált Magyarországon ennyire fontossá a magyar nyelv szabályainak meghatározása és folyamatos terjesztése, akkor minden bizonnyal Kazinczy Ferencig, a nyelvújításig kell visszatekintenünk. „A 18. század végén és a 19. században a magyar irodalom a politikával is összefonódott s a nyelvpallérozással is (az etalon mindkét tekintetben Kazinczy); [...] Úgy tűnik, a magyar kultúrába mélyen beépült az irodalom-

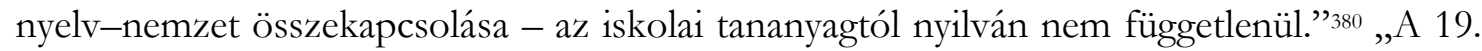
század eleji felvilágosodás és reformkor ültette el mélyen a magyar köztudatban azt, hogy a nemzeti lét alapja a nyelv, általában a nyelv érték, amelyet lehetőség szerint mindenkinek gondozni és fejleszteni kell." ${ }_{381}$ Nem véletlen, hogy ebben a korban alapították a Magyar Tudományos Akadémiát (1825), és az Akadémia gondozásában nem sokkal később jelent meg az első helyesírási szabályzat, a Magyar helyesírás' és szóragasztás' fôbb szabályai (1832). Szerkesztői kellő türelemmel és alázattal kezdtek a munkához; Döbrentei Gábor titoknok előszava e gondolatokkal zárul: „Nem akarván ennél fogva a’ Társaság, az általa megállítottra nézve, egyszer mindenkorra lenni parancsoló, szabadjokra hagyja még tagjainak is, hogy e' szabásokat, midőn tulajdon személyükben állnak elé munkájokkal, általlátásukhoz képest követhessék. Győzzön a' mi jobb! ez a' Társaság’ szava, okokkal kíván ő vezetője lenni a' kivilágulás szerint alakuló köz megegyezésnek, fennhéjázó 's önkényü vezér nem." 382 - E folyamat további, immár a szóbeliséget érintő állomása volt Kodály Zoltán 1937. december 9-én az Eötvös Kollégium volt tagjai szövetségének közgyúlésén Riadó címmel elmondott - szúk egy évvel később a rádió nyilvánossága előtt megismételt - beszéde, melyben Kodály így fogalmazott: „Nálunk semmi beszédkultúra, semmi oktatás nincs, sőt a hangzó beszéd alaptörvényei sincsenek tisztázva.”383 A figyelemfelhívás nyomán rendezték meg 1939-ben Budapesten az első egyetemi kiejtési versenyt, 384 amelyet még kettő követett; e kezdeményezés utódjának tekinthetjük a Péchy Blanka által létrehozott Kazinczyalapítványt, amelynek támogatásával 1966-ban megrendezhették - s azóta is évente megrendezik - a középiskolások kiejtési versenyét.

\section{A nyelvhasználat szerepe az állami szervezeteknél}

Mint föntebb láthattuk, viták folynak arról, hogy miként értékelendő a nyelv sztenderdizálása, miként arról is, hogy mennyire lehetünk elnézőek a mindennapokban a nyelvi (helyesírási, kiejtési, nyelvhelyességi) hibákat ejtő embertársainkkal szemben. Egyáltalán mit tekintsünk hibának? De vajon mi a szerepe a sztenderdizált nyelvnek, a helyes nyelvhasználatnak az állami szervezetek esetében? Öncélú akadékoskodásnak vagy céltudatos elvárásnak tekinthető-e, ha kijelentjük, hogy az állami (közigazgatási, rendészeti) szervezet minden megnyilvánulásának hiánytalanul követnie kell a sztenderdizált nyelv szabályait? Magyarán: helyesírási hiba, nyelvhelyességi probléma, illetve érthetetlen, rossz kiejtéssel elmondott szóbeli közlés e körben nem fordulhat elő?

\footnotetext{
380 SÁNDOR i. m. (2001) pp. 241-259.

381 BALÁZs i. m. (2018) pp. 55-56.

382 Idézi: A magyar helyesírás szabályai. 12. kiad. Akadémiai Kiadó, Bp., 2015. (az előzéklapon)

383 Idézi: Z. SzABÓ László - WACHA Imre: A Kazinczy-versenyek története. Győr, 1978. p. 7.

${ }^{384}$ A verseny egyik nyertese Lőrincze Lajos volt.
} 
Természetesen megeshet, hogy az állami (közigazgatási, rendészeti) szervezet kommunikációja - akár írásban, akár szóban - hibákat tartalmaz. Ez elő is fordul nap mint nap. Célul kell azonban kitűzni, hogy a mindannyiunk érdekében, mindannyiunk adójából tevékenykedő, valamennyiünkre kötelező döntéseket hozó állami szervezetek nyelvhasználata mind írásban, mind szóban kifogástalan legyen. Három gyakorlati szempontot vázolok föl a továbbiakban ennek a kijelentésnek az alátámasztására. Példáimat pedig a Nemzeti Adó- és Vámhivatal (NAV) háza tájáról hozom, tekintettel arra, hogy e szervezetet, illetve egyik jogelődjét ismerem közelebbrôl immár három évtizede ${ }^{385}$, illetve ennek kommunikációját kutatom.

\section{Szervezeti kultúra és nyelwhasználat}

Mi is tulajdonképpen a kultúra? A Magyar Értelmező Kéziszótár szerint a szó első jelentése: „az emberiség által létrehozott anyagi és szellemi értékek összessége. - A művelődésnek vmely területe, ill. vmely korszakban, vmely népnél való megnyilvánulása". ${ }^{386}$ A kultúra fogalmának széles körben elterjedt és elfogadott kifejtését olvashatjuk Geert Hofstede és Gert Jan Hofstede művében. A szerzôpáros a kultúrát mentális programnak, az elme szoftverének tartja, mert - mint írják - ,a kultúrát tanuljuk, nem velünk született dolog”. ${ }^{387}$ A kultúra másik ismérve, hogy „mindig kollektív jelenség, mivel legalább részben meg kell osztanunk olyan emberekkel, akik ugyanabban a társadalmi környezetben élnek vagy éltek, amelyben a kultúrát elsajátítottuk". 388 A szerzőpáros a kultúra megnyilvánulási formáit (szimbólumok, hősök, rítusok, értékek) egy hagyma rétegeiként képzeli el, aszerint elhelyezve azokat, hogy melyik mennyire mély vagy ellenkezőleg, mennyire felszínes megnyilvánulása az adott embercsoport kultúrájának. A szervezeti kultúra felépítésének egyik legismertebb, Schein által megalkotott modellje ${ }^{389}$ szerint a szervezet mindenki számára látható jellemzői között szerepel (a szervezet fizikai környezetének felépítése, technológiája, termékei, közzétett értéklistái, megfigyelhető rituáléi és szertartásai stb. mellett) a szervezet által használt nyelv. ${ }^{390}$ Mindebből következik, hogy a nyelv a szervezeti kultúra egyik megnyilvánulása. Egy szervezet tehát a nyelvhasználata által is közvetíti a számára fontos értékeket, mind a belső, mind pedig a külső kommunikáció során. Melyek a NAV számára fontos értékek? Mielőtt ezt kifejtem, fontos tisztázni a NAV jogállását, mert ez meghatározza az általa követendő/követett értékeket is. „A Nemzeti Adó- és Vámhivatal (NAV) államigazgatási és fegyveres rendvédelmi feladatokat ellátó, a Kormány eredeti jogalkotói hatáskörében kiadott rendeletében kijelölt miniszter által irányított, központi hivatalként múködő központi költségvetési szerv." ${ }^{311}$ A NAV tehát egyrészt államigazgatási, másrészt rendvédelmi jellegü, harmadrészt pedig központi szervezet. Érvényesnek tekinthetjük tehát a NAV-ra nézve is Molnár Katalin megállapítását: „a kommunikációnak meghatározó szerepe van a rendészeti munkában, s erre már a

\footnotetext{
385 A szerző 1991 óta pénzügyőr; akkor kezdte szolgálatát a Nemzeti Adó- és Vámhivatal egyik jogelődjénél, a Vám- és Pénzügyőrségnél.

386 JUHÁsz József et al. (szerk.): Magyar Értelmező Kéziszótár. Akadémiai Kiadó, Bp., 1993. pp. 799-800.

387 Hofstede, Gert - Hofstede, Gert Jan: Kultúrák és szervezetek. Az elme szoftvere. VHE Kft., Pécs, 2008. p. 35.

388 uo.

389 Schein modelljét jéghegyként, a látható elemeket a jéghegy látható részeként szokták említeni és ábrázolni; az idézett múben viszont nem szerepel a ,jéghegy” kifejezés, továbbá a szerző nem jéghegyként ábrázolja modelljét.

390 SCHEIN, Edgar H.: Organizational culture and leadership, Jossey-Bass, San Francisco, 1985. pp. 25-26.

391 2010. évi CXXII. törvény a Nemzeti Adó- és Vámhivatalról, 1. \(1) bek.
} 
szakemberek képzése során kiemelt figyelmet kell fordítani”. ${ }^{392}$ A követendő értékekről képet kaphatunk a NAV 2021-es munkatervéből, 393 amely szerint folytatni kell a közérthető kommunikáció már megkezdett fejlesztését, a többi között a Közérthetőségi Program folytatása, illetve a program 2.0 verziójának kidolgozása, továbbá automatikus szövegjavító alkalmazás fejlesztése révén. A foglalkoztatottakkal szembeni elvárásokat pedig az elmúlt időszakban elkészült kompetenciatérkép tartalmazza. A témánk szempontjából releváns követelmények: kommunikációs készség, önfejlesztés és tanulási készség, szabálykövetés és fegyelmezettség. ${ }^{394} \mathrm{Ha}$ mindezeket egybevetjük, ráadásul közelről szemléljük a NAV Kommunikációs Főosztályának erőfeszítéseit, látható, hogy a sztenderd nyelv használata (a helyesírás, a nyelvhelyesség, a helyesejtés) a NAV szervezeti kultúrájának fontos eleme. Utóbbi, a helyesejtés javítása immár beszédtanár közremúködésével történik. ${ }^{395}$

S némi történeti előzmény: a Vám- és Pénzügyőrség belső újságjában, a Pénzügyőrök Lapjában igen hasznos rovat indult útjára 1972-ben: a nyelvművelő rovat. Szalkai Pálírta az ez évben megjelent első három cikket: Nyelvi egyveleg, ${ }^{396}$ Különírás - egybeírás ${ }^{397}$, illetve Nyelvi múveltség ${ }^{398}$ címmel. Utóbbi így kezdődik: „Aki a magyar nyelv szabályai ellen írásban vagy beszédben vét, attól még lehet jó magyar hazafi, és választott hivatásának, szakmájának kiváló múvelője. A nyelvi szabályok ismerete ma már szinte külön szakma, tudomány, nemcsak egyszerűen iskolai tantárgy. A szabályok ismeretének persze vannak fokozatai, mint ahogy a nyelvi vétségek is kisebbek vagy súlyosabbak." 399

\section{Van-e nyelvmüvelo" szerepe a $N A V$-nak?}

Ha már föltettem az első pillantásra furcsának ható kérdést, rögtön válaszolok is rá: igen, van! Legalábbis kellene, hogy legyen. Ugyanis, ha egy szervezet komolyan gondolja, hogy magas szintű szervezeti kultúrát alakít ki, akkor annak is tudatában kell lennie, hogy ez a szervezeti kultúra és ennek minden megnyilvánulása - a külső szervezeti kommunikáció révén - hat a társadalom tagjaira. Molnár Katalin részletesen ír erről, taglalva az egyes rendészeti szervezetek - köztük a NAV - társadalmi szerepét és ennek szerves részeként külső kommunikációjuk jellegzetességeit. ${ }^{400}$ Még gyakorlatiasabb szemszögből: 2019-ben a nav.gov.hu-ról több mint 17 millió letöltés történt, a gazdasági tevékenységet folytató adózók száma mintegy 2 millió, a személyi jövedelemadót bevalló magánszemélyeké 5 millió volt. 401 A NAV tehát szinte minden magyar állampolgárral kapcsolatban áll. Vagyis: ahogyan mint szervezet és ahogyan annak egyes tagjai kommunikálnak, az öntudatlanul is hat a velük kapcsolatba kerülő ügyfelekre.

\footnotetext{
392 MOLNÁR Katalin: A kommunikáció szerepe a rendészeti munkában. A kommunikációs készségek fejlesztési lehetőségei a rendészeti képzésben. Határrendészeti Tanulmányok, 2016/1. szám. pp. 51-54.

$393 \quad$ NAV Intézményi 2021. https://www.nav.gov.hu/nav/kozerdeku adatok/kulonos kozzeteteli lista/strategia/NAV Intezmenyi M unkat20210429.html (Letöltve: 2021. május 20.)

${ }^{394}$ Kompetenciatérkép ügyintézők számára. \#hivatal (A NAV lapja) III. évf. 1. szám, 2021. március, pp. 12 13.

395 LASZKÁCs Ágnes: Sajnos itt se szusi sül. \#hivatal (A NAV lapja) III. évf. 1. szám, 2021. március, p. 28.

396 Szalkai Pál: Nyelvi egyveleg. Pénzügyőrök Lapja, XXIV. évf. 1972/8-9. szám. p. 10.

397 Szalkai Pál: Különírás - egybeírás. Pénzügyőrök Lapja, XXIV. évf. 1972/12. szám. p. 7.

398 Szalkai Pál: Nyelvi műveltség. Pénzügyőrök Lapja, XXIV. évf. 1972/10. szám, p. 7.

399 uo.

400 MOLNÁR Katalin: Rendészeti kommunikáció - a média tükrében. Kézikönyv és szemelvénygyüjtemény a rendészeti szakújságíró szakirányú továbbképzési szak hallgatóinak. Dialóg Campus Kiadó, Bp., 2018.

${ }^{401}$ NAV évkönyv 2019. https://www.nav.gov.hu/nav/kiadvanyok (Letöltve: 2021. május 20.)
} 
Péchy Blanka véleménye ,szerint ma olyan fontos a helyes magyar beszéd, miként a nyelvújítás korában maga a nyelv volt, hiszen a film, a rádió, a televízió közvetítésével egyegy hang egyidejűleg százezrekhez és milliókhoz jut el, egyszerre tömegeket nevelhet a helyes magyar beszédre.” 402 Balázs Géza így fogalmaz: „Szükség van arra, hogy az egyik legnagyobb nyelvbefolyásoló erő, a média átgondolt, választékbővítő, példát mutató, ismeretterjesztő, ha úgy tetszik: tanító minta legyen". ${ }^{403}$ Úgy gondolom, hogy az általam kiemelt kívánalom - a média tanító minta legyen - megfogalmazható mindenkire és minden szervezetre, aki, amely sok emberrel áll kapcsolatban, s így módja és lehetősége (!) van a nyelvmûvelésre. Igaz ez a közigazgatás és a rendészet szervezeteire, s mint ilyenre, a NAV-ra is.

\section{A csalók nem jártak nyelvtanórára - vagy ba igen, nem figyeltek}

Végül egy nagyon gyakorlati szempontra hívom föl a figyelmet, amely összefügg a szervezeti kultúra kérdésével is. Örömteli folyamat, hogy a magyarországi közigazgatás egyre nagyobb mértékben e-közigazgatásként múködik. Ebben kiemelt szerepe van a NAV-nak; rövid idôn belül az állami adó- és vámhatóság lehet az első teljesen papírmentes hivatal. A digitális tér azonban veszélyeket is rejt magában. Szerencsére nem túl gyakran, de előfordul, hogy bűnözôk a NAV nevével és arculati elemeivel visszaélve olyan üzeneteket küldenek számos ímélcímre, amelyben valamilyen előnnyel (mondjuk adó-visszatérítés lehetőségével) kecsegtetve rábírják a címzettek egy részét, hogy érzékeny adatokat adjanak meg magukról.

Álljon itt csak egy példa a Nemzeti Kibervédelmi Intézet (NKI) riasztásai közül: „A Nemzetbiztonsági Szakszolgálat Nemzeti Kibervédelmi Intézet (NBSZ NKI) információi szerint jelentős növekedés tapasztalható a NAV nevével visszaélő adathalász tevékenységekkel kapcsolatban. Az adathalász csalók a közelgő adóbevallási időszakra hivatkozva igyekeznek bizalmas információkat szerezni, ezt leggyakrabban az üzenetekben található link segítségével próbálják meg elérni, amely egy adathalász honlaphoz vezet.” ${ }^{004}$ A riasztást több képernyőkép illusztrálja, ezek közül alább látható az egyik.

\footnotetext{
402 Idézi: Z. SZABÓ László - WACHA Imre: A Kazinczy-versenyek története. Győr, 1978. p. 20.

403 BALÁzs Géza: A közszolgálatiság mint nyelvgazdagítás. In: BOGNÁR Nándor (szerk.) Anyanyelvi konferencia, 2003. december 1. Magyar Rádió, Bp., 2003. pp. 79-84. (Kiemelés tőlem: S. L.)

404 Tájékoztatás a NAV nevével visszaélő adathalászattal kapcsolatban (2020. január 14.) https://nki.gov.hu/figyelmeztetesek/tajekoztatas/tajekoztatas-a-nav-nevevel-visszaelo-adathalaszattalkapcsolatban/ (Letöltve: 2021. május 20.)
} 


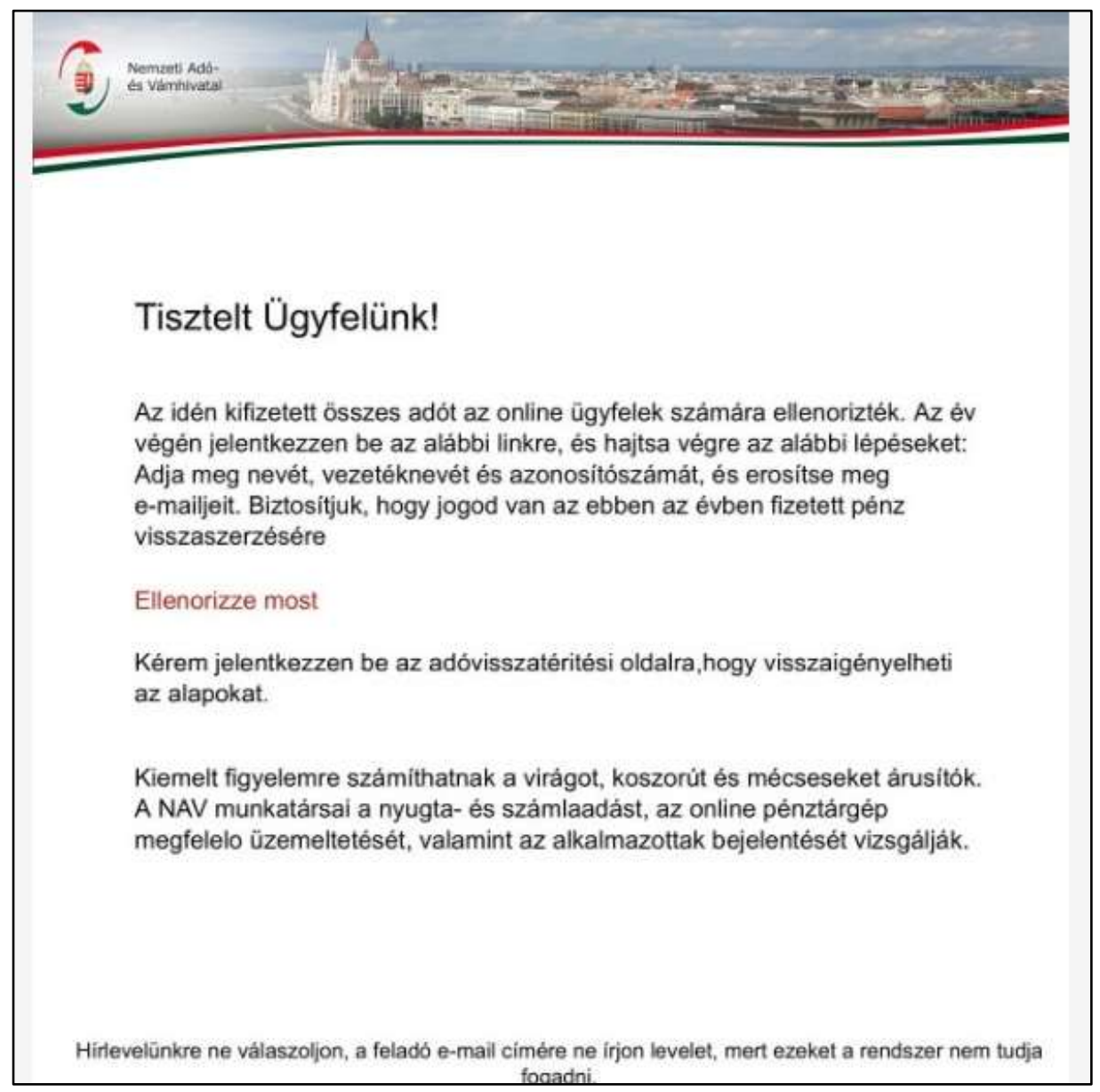

1. kép: NAV adathalász levél bemutatása a Nemzeti Kibervédelmi Intézet honlapján. Forrás: https://nki.gov.hu / figyelmeztetesek/tajekoztatas/tajekoztatas-a-nav-nevevel-visszaeloadathalaszattal-kapcsolatban/ (Letöltve: 2021. május 20.)

Mint látható (és erre az NKI is figyelmeztet), az üzenet már első ránézésre is gyanút kelthet, a nyelvtani hibák és a hivatalostól eltérő nyelvezet - például a következetlenül váltakozó tegező és magázó megszólítás - miatt. Az adóhivatal továbbá (mivel a saját szemszögéből fogalmaz) nem „kifizetett”, hanem „, befizetett” adóról írna, illetve a pénz „visszaszerzése” sem vall hivatalos levélre. Végül pedig az utolsó bekezdés mondandója egyáltalán nem kapcsolódik az előző tartalomhoz.

Mi ebből a tanulság? Addig, amíg az internetes csalók igényessé nem válnak nyelvhasználatukat illetően, a valós hivatali üzenetek (legalábbis nyelvi szempontból) jól megkülönböztethetőek az adathalászok által küldöttektől az igényes, szabályos nyelvhasználat révén.

\section{Összegzés}

A magyar nyelv, hasonlóan a legtöbb európai nyelvhez, sztenderdizált, ráadásul erős normaközpontúság jellemzi. Ezzel összefüggésben tapasztalható jelenség a lingvicizmus, a nyelvi diszkriminizáció, amelynek egyik formája a nyelvet helytelenül használók negatív megkülönböztetése. A nyelvészek egy része - s mellettük mások, köztük a szerző is fontosnak tartja a nyelvművelést, illetve ennek előfeltételeként a nyelv sztenderdizációját. A nyelvmúvelésnek több évszázadra visszanyúló hagyománya van Magyarországon, s a szerző 
meglátása szerint az állami szervezetek kommunikációjának egyik szerepe is éppen az, hogy „tanító minta legyen”. A közigazgatási és a rendészeti szervezetrendszer szervezeti kultúrájának szerves része a nyelvhasználat, amely sokat elmond az adott szervezetről. Végül pedig nem mellékes gyakorlati szempont, hogy a digitális világban az internetes csalók üzeneteitôl a nyelvhasználat révén is meg lehet különböztetni a hatóság által küldött valódi tartalmakat.

\section{Felhasznált irodalom}

[1] 2010. évi CXXII. törvény a Nemzeti Adó- és Vámhivatalról

[2] A magyar helyesírás szabályai. 12. kiad. Akadémiai Kiadó, Bp., 2015.

[3] BALÁzs Géza: A fenntartható magyar nyelv. Nyelvépítészet - nyelvösszeomlás nyelvstratégia. Inter-IKU, Bp., 2018.

[4] BALÁzs Géza: A közszolgálatiság mint nyelvgazdagítás. In: Bognár Nándor (szerk.) Anyanyelvi konferencia, 2003. december 1. Magyar Rádió, Bp., 2003. pp. 79-84.

[5] BALÁzs Géza: Hatalom és helyesírás. In: BOZsIK Gabriella (szerk.) Két évtized a helyesírásért. EKF Líceum Kiadó, Eger, 2008. pp. 15-27.

[6] Hofstede, Gert - Hofstede, Gert Jan: Kultúrák és szervezetek. Az elme szoftvere. VHE Kft., Pécs, 2008.

[7] HoRvÁth Lajos: Beszéd a rádióban. Tanácsok kezdőknek és haladóknak. Magyar Rádió Rt., Bp., 2002.

[8] JÁNK István: A helyesírás-tanítás helye és szerepe a nyelvtanórán és az iskolában. ACTA Universitatis de Carolo Esżterbázy nominatae, Sectio Linguistica Hungarica, 2020/46. szám. pp. 45-56. https://doi.org/10.46437/actauniveszterhazylinguistica.2020.45

[9] JuHÁsz József et al. (szerk.): Magyar Értelmező Kéziszótár. Akadémiai Kiadó, Bp., 1993.

[10] Kompetenciatérkép ügyintézők számára. \#hivatal (A NAV lapja) III. évf. 1. szám, 2021. március, pp. 12-13.

[11] LASZKÁCS Ágnes: Sajnos itt se szusi sül. \#hivatal (A NAV lapja) III. évf. 1. szám, 2021. március, p. 28.

[12] MOLnÁr Katalin: A kommunikáció szerepe a rendészeti munkában. A kommunikációs készségek fejlesztési lehetőségei a rendészeti képzésben. Határrendészeti Tanulmányok, 2016/1., pp. 51-54.

[13] MOLNÁR Katalin: Rendészeti kommunikáció - a média tükrében. Kézikönyv és szemelvénygyűjtemény a rendészeti szakújságíró szakirányú továbbképzési szak hallgatóinak. Dialóg Campus Kiadó, Bp., 2018.

[14] NAgY László: Metanyelvi ismeretek, nyelvi attitűdök, értékítéletek vizsgálata tanítójelöltek körében. Doktori értekezés. Szeged, 2018. https://doi.org/10.14232/phd.9886

[15] NAV évkönyv 2019. https://www.nav.gov.hu/nav/kiadvanyok (Letöltve: 2021. május 20.)

[16] NAV Intézményi Munkaterv 2021. https://www.nav.gov.hu/nav/kozerdeku adatok/kulonos kozzeteteli lista/strategi a/NAV Intezmenyi Munkat20210429.html (Letöltve: 2021. május 20.)

[17] SÁNDOR Klára: „A nyílt társadalmi diszkrimináció utolsó bástyája” az emberek nyelvhasználata. Replika, 2001/11. szám. pp. 241-259.

[18] SCHEIN, Edgar H.: Organizational culture and leadership, Jossey-Bass, San Francisco, 1985. 
[19] SZALKAI Pál: Különírás - egybeírás. Pén₹ügyörök Lapja, XXIV. évf. 1972/12. szám, p. 7.

[20] SZALKaI Pál: Nyelvi egyveleg. Pénzügyórök Lapja, XXIV. évf. 1972/8-9. szám, p. 10.

[21] Szalkai Pál: Nyelvi műveltség. Pénqügyörök Lapja, XXIV. évf. 1972/10. szám, p. 7.

[22] Tájékoztatás a NAV nevével visszaélő adathalászattal kapcsolatban (2020. január 14.) https://nki.gov.hu/figyelmeztetesek/tajekoztatas/tajekoztatas-a-nav-nevevelvisszaelo-adat halaszattal-kapcsolatban/ (Letöltve: 2021. május 20.)

[23] Z. SZABÓ László - WACHA Imre: A Kazinczy-versenyek története. Győr, 1978.

\section{Lektor}

Molnár Katalin, Dr., egyetemi docens,

Nemzeti Közszolgálati Egyetem Rendészettudományi Kar,

Rendészeti Magatartástudományi Tanszék, molnar.katalin@uni-nke.hu 